countries, but also about articles published in the major periodicals and other reference works of the world (covering some 500 periodical or continuing titles).

The price for the 1967-1976 volume is not yet available, but the 19771980 volume and the 1981 supplement are priced respectively at SWF 220 and SWF 80. Orders should be sent to:

\author{
Nordic Law Consultants \\ 4 , rue de la Rôtisserie \\ 1204 Genève \\ Switzerland
}

\title{
USSR CODE OF LAWS
}

The Soviet Union has begun to publish a systematic codification of its all-Union laws under the title "Svod Zakonov SSSR". In addition to statutes enacted by the Supreme Soviet of the USSR, the code includes important decrees of the Central Committee of the Communist Party of the Soviet Union and the USSR Council of Ministers. The laws and decrees are arranged by subject in twelve volumes, and each volume consists of one or more looseleaf binders suitable for regular updating. Supplementation for each published volume is expected to occur once or twice a year. The arrangement of the code is as follows:

Volume 1 Social and Government Structure of the USSR

Volume 2 The Civil Code, Marriage and Family, Labor, and Social Welfare

Volume 3 Health, Physical Culture and Sports, Education, Science, and Culture, and the Regulation of Foreign Citizens and Stateless Persons

Volume 4 Natural Resources

Volume 5 Economics and Finance

Volume 6 Capital Development

Volume 7 Industry

Volume 8 Agriculture and Other Rural Economy Matters

Volume 9 Transport, Communication, Trading, Supply of Food and Other Commodities, and Housing

Volume 10 International Relations, Foreign Trade, Defense, and Protection of Borders

Volume 11 The Judiciary and Procuratorial Systems of the USSR

Volume 12. Indices and Other Finding Aids 
The first volume of the code has already been issued to subscribers. Subsequent volumes are expected to be published at regular intervals through 1985. It should be noted that the language of the code is Russian.

Published by the Izvestiya Press, the code is tentatively priced at 10 roubles for each volume. Subscriptions outside the Soviet Union should be placed with local distributors of Soviet books.

Several Soviet Republics have announced that they are also preparing systematic codifications of their separate republican laws, but the details of such codification projects are not yet available.

\section{NEW PERIODICAL FOR LAW LIBRARIANS}

Legal Reference Services Quarterly is a new periodical for law librarians in the United States.

Created for the purpose of enhancing the knowledge of law librarians about the continuously expanding volume of legal materials and their utility in legal research, this new periodical is expected to survey in the shape of articles or bibliographic reports the available sources of information about specific topics of law.

The first issue, dated Spring 1981, clearly demonstrates these editorial aims. It contains a rich variety of useful bibliographic surveys, including:

- an analysis of essential research tools for criminal defense attorneys, by William Goodman, a San Francisco attorney;

- an annotated bibliography of non-legal reference books for law libraries, by W. Leslie Peat, Law Librarian at the University of Vermont Law School;

- a study of obscenity research materials, by Virginia Frost, a law firm librarian in Providence, Rhode Island;

- a bibliography of federal administrative decisions, by Nancy $P$. Johnson, University of Illinois Law Library;

- a detailed review of Corpus Juris Secundum, by Robert C. Berring, Law Librarian of the University of Washington Law Library in Seattle, Washington, and Valerie Wedin, Research Assistant at Harvard Law Library.

There is also a section entitled "Notes and Trends", which describes developments in legal research. Future issues will contain another section - "Law on Line"-dealing with machine readable data bases of interest to lawyers. 